This is an Authors' Original Manuscript of an article to be published in POLICY STUDIES, copyright Taylor \& Francis, anticipated June 2013 online publication at: http://www.tandfonline.com/

\title{
Creating sustainable employment opportunities for the unemployed
}

McBride, A. and Mustchin, S.

Manchester Business School, The University of Manchester, Booth Street West, Manchester, M15 6BP.

Tel: 0161306 5863; Fax: 0161306 3505;

a.mcbride@manchester.ac.uk; stephen.mustchin@manchester.ac.uk

Correspondence to be directed to Anne McBride 


\title{
Creating sustainable employment opportunities for the unemployed
}

\begin{abstract}
This article addresses challenges associated with creating sustainable employment opportunities for the unemployed and encouraging employer engagement in skills development and utilisation more generally. Survey and case study analysis of an initiative introduced by New Labour in the National Health Service England (NHS) provides evidence of employer reluctance to engage with a policy which addresses social exclusion and unemployment. Reasons are presented for this policy to implementation gap. This behaviour, in a buoyant economy, underlines a broader concern that voluntarism will be insufficient in the current economic climate to encourage employers more generally to adopt longer-term workforce development strategies. This reluctance to engage is compared with those NHS employers who were motivated to develop intermediate labour markets for the unemployed with explicit links to their internal labour markets, thereby providing opportunities for work experience and job progression. Implications are drawn from these contrasting behaviours as to how the state can encourage more employers to adopt progressive practices.
\end{abstract}

Keywords: unemployment; sustainable employment; employability; NHS; New Labour; Healthcare management

\section{Introduction}

As the UK faces the highest unemployment rates for decades, record unemployment amongst the under-24s and an urgent need to expand the economy, policy attention is being focused on supporting sustainable growth (DBIS 2010) and sustainable employment (UKCES 2011a). These aspirations, however, need to be set against the UK's preoccupation with getting people into work as quickly as possible and a tendency towards supply-side solutions to economic growth and skills development. The demandside weakness of the UK's approach to workforce development is underpinned by gaps in policy, and gaps between policy and practice (UKCES 2009). In addition to needing to identify a more progressive approach to welfare to work policies (Newman 2011), more knowledge is required about what works for employers (Devins et al 2011; Newman 2011) and how best to raise their 'ambition' (UKCES 2009).

Welfare to work schemes have often focused on supply side interventions which have a tendency to provide short-term labour market attachments and repeat episodes of unemployment (Convery 2009). In contrast to such schemes which tend to leave employers as passive actors, the initiative reviewed in this article - called the Skills Escalator - encouraged NHS employers to develop schemes which involved job creation, job transition and job progression. This initiative was aimed at the 400-plus employers in the National Health Service England (NHS) which employs approximately 1.4 million staff.

This article aims to show that the Skills Escalator has a number of characteristics of the Human Capital Development (HCD) approach to employability (Lindsay et al. 2007) which focuses on sustainable transitions to work and job progression. Survey and case study material is used to underline the extent to which public sector employers share private sector reluctance to engage with schemes for the unemployed - even in buoyant times. Notwithstanding, the research did reveal several organisations who with external 
funding - and a different perspective - took an HCD approach and established work placements for the unemployed which were integrated into the work of the organisation and linked to their internal labour markets.

The article follows in three sections. The first section establishes the need for sustainable employment and, using Lindsay et al's (2007) framework, identifies key components of an HCD approach which employers are reluctant to adopt. The section ends with an identification of the research questions and methods underpinning the article. The second section presents the findings. It begins by analysing the HCD potential of the Skills Escalator and the context of its introduction, before identifying the extent of employer reluctance to adopt this initiative and presenting contrasting employer activity and motivations in three case study sites. The final section discusses the implications of these findings for the development of labour market policy in the current economic context.

\section{Creating sustainable employment - why the challenge?}

Sustainable employment refers to an individual remaining in work, or work that provides opportunities for workers to advance and earn more (National Audit Office 2007, p.7). Creating such employment offers at least three challenges for governments and employers - accepting it is necessary, identifying more fully what is required of employers and considering how to encourage employer engagement. Regarding the first challenge, whilst high levels of unemployment in a contracting economy might attract comments that 'any job is better than no job', studies of schemes to encourage individuals from welfare to work consistently point to the limitations of what has become known as the 'Work First' (WF) approach (Lindsay et al 2007). WF approaches focus on getting people into work as quickly as possible, inserting job seekers into available opportunities and providing them with short-term training. Jobs associated with WF approaches, however, are often low paid and are associated with trapping people in poverty (Newman 2011). They have also been associated with churn (Convery 2009). In addition, evidence from previous unemployment schemes suggests that concentrating on supply-side mechanisms, such as short-term training schemes, is unlikely to affect the aggregate demand for jobs (Peck and Theodore 2000; Newman 2011). Indeed, without job creation or job development, there is a danger that large flows of the unemployed displace low wage workers, leading to wage decline and adverse consequences for the working poor (Peck and Theodore 2000). There is a growing acceptance of the need for sustainable employment (National Audit Office 2007, UKCES 2011a) but acceptance does not necessarily translate into pertinent action as seen in the recent policy for sustainable growth which makes no mention of the need for sustainable employment (DBIS 2010).

The second challenge is of identifying more fully the activity required of employers. Employers who provide longer term opportunities could be conceptualised as taking a human capital development (HCD) approach. In contrast to WF, these approaches support sustainable transitions to work, longer-term training and progression across a range of job opportunities (Lindsay et al 2007, p. 542). Five factors are identified as being central to progression: availability of high quality jobs; self-efficacy; career development; access to training; and progression pathways (Devins et al 2011) but less 
attention has been paid to how employers might pull these aspects together. Comparison of WF and HCD approaches in the context of extant literature indicates at least three practices which could support an HCD approach - intermediate labour markets, internal labour markets and labour market intermediaries.

Firstly, the programme target of an HCD approach is 'sustainable transitions to work at range of skill levels with progression routes once in work' as opposed to an 'immediate emphasis on job entry' (Lindsay et al 2007, p. 542). Intermediate labour markets and subsidised work placements can arguably support sustainable transitions as they provide a space within which the unemployed can gain skills and confidence with a view to keeping themselves employable and encouraging their longer-term attachment to the labour market (Marshall and Macfarlane 2000, Daguerre with Etherington 2009). Another means of providing such experience is in job rotation schemes (Parker 2001, Etherington and Jones 2004) which take workers in relatively low skilled jobs on training programmes (to enable them to progress into higher levels jobs), releasing jobs in an intermediate labour market for the unemployed.

Second, the HCD approach is characterised by a relationship to the labour market which 'encourages and supports progression routes in workplace' (Lindsay et al 2007, p. 542), in contrast to the demand-responsive approach of WF. Remuneration, conditions of work, working hours, opportunities for progression, availability of 'entry-level' positions, and employers' formal recruitment and selection procedures are all factors which influence a person's employability (McQuaid and Lindsay 2005, p. 209) and are key dimensions of an internal labour market. Such markets are generally assumed to be insulated to some extent from the economic variables that characterise external labour markets but they do require employers to develop appropriate HR policies around training provision, transparent career structures and equitable rates of pay. Indeed, the job rotation scheme noted above requires an internal labour market from which to develop and promote employees.

Third, employers may need the services of labour market intermediaries in an HCD approach. WF schemes emphasise job searches and job entry into available opportunities with a focus on immediate activity. Such schemes are more likely to lead to 'revolving door' participation' (Lindsay et al 2007). The focus on sustainable transitions to work, rather than 'quick wins', however, may require the presence of a integrated labour market intermediary who brokers this relationship between the potential employee and the employer (Benner 2003, Clayton and Brinkley 2011). The use of labour market intermediaries in state-supported labour market interventions however, is not unproblematic - not least because they rely on contingent funding sources (Benner 2003) and in the UK have been associated with meeting employers' short-term labour needs (Gore 2005).

This leads us to the third challenge - how to encourage employers to engage in an HCD approach which facilitates the longer term attachment of the unemployed to the labour market. As indicated, such approaches are likely to require the integration of supply and demand-side interventions and may rely on the creation of intermediate labour markets, internal labour markets and the use of labour market intermediaries. Aside from these operational details, moving from a WF to HCD approach requires a different policy direction from governments. A review of EU-wide developments in welfare reform indicates that attempts to improve human capital have in general been 'unimpressive', 
and the emphasis within active labour market policies has most prominently focused on 'activation through benefit redesign rather than positive support for mobility between jobs' (Taylor-Gooby, 2008: 11). Conservative-led coalition (CLC) reforms of the UK welfare system continue this tendency towards WF (Clayton and Brinkley 2011).

Whilst New Labour stand accused of laying the foundations of WF and increasing welfare conditionality (Newman 2011), during New Labour's period of office there were a number of small scale initiatives which encouraged a different approach from employers and communities to welfare to work policies (see Lindsay et al 2007, Houghton 2008, Fuller et al 2010, South et al 2011). The study of two such schemes led Lindsay et al (2007) to argue that whilst there was no demonstrable shift to a coherent, HCD-oriented approach in the UK, progress was being made towards a hybrid system which promoted 'some (original italics) forms of HCD' (p. 557). Any progress requires a move away the 'quick-wins' mentality of many unemployment schemes and more active engagement by employers.

Employers, however, are reluctant to engage with more expansive schemes and, indeed, are free to do so in the voluntarist, deregulated context of the UK. They have often accepted high labour turnover in low skilled jobs rather than taking remedial action, and have created barriers to the unemployed through their vacancy communication, lack of comprehensive induction courses and limited training opportunities (Devins and Hogarth 2005). Moreover, there is little evidence that labour market intermediaries, employers or the individuals themselves view low skilled work as a step towards progression (Devins et al 2011). This reluctance to engage reflects the broader tendency of employers to be consumers of publicly funded provision which supplies them with skills or qualifications which the state thinks employers need (Keep et al 2010, pp. 41314), rather than being more proactive and devising more fundamental, longer-term schemes which might enable them to meet the development aspirations of themselves and employees. The UK Commission for Employment and Skills (UKCES) identifies this limited focus on skills development as a demand-side weakness, and argues for investment in raising employer ambition and stimulating demand (UKCES 2009). Despite two of their priorities relating to employer engagement (UKCES 2011b), as indicated by Payne and Keep (2011, p. 15), the question remains,

how in a voluntarist training system and de-regulated labour market, and given existing levels and patterns of employer demand for skill, can employers be persuaded to substantively increase their investment in training this time round?

Governments provide a range of grants and subsidies to encourage employers and workers to get involved in training (McQuaid et al 2011) and local authorities have used planning regulations to ensure that relocating employers provide pre-employment training for unemployed citizens (Fuller et al 2010). Subsidies, however, do not always overcome employer reluctance (Payne and Keep 2011). Perhaps unsurprisingly research indicates that employers are more likely to support induction and continual development practices in a tight labour market (Devins and Hogarth 2005) and demand-led programmes for the unemployed are highly dependent on labour markets with significant quantities of entry level job vacancies (Fletcher 2004).

Both of these conditions were to be found in the NHS at the time the Skills Escalator was introduced (Wanless 2002). In addition, the Labour government 
(Department of Health 2000) announced its intention to increase spending in the NHS by an annual average real terms growth of 6.3 per cent (p. 41). Indeed, the Skills Escalator was part of a range of Human Resource (HR) policies implemented by the Labour government which from 2001 onwards sought to reform and expand the NHS workforce (Department of Health 2002, Bach 2004). We might expect, therefore, that NHS employers would be keen to implement such a policy enabling us to learn more about what motivates employers and what works for them (Newman 2011, Devins et al 2011).

After identifying the HCD potential of the Skills Escalator in abstract, important first empirical questions relate to how employers respond to this initiative in an expanding economy and discovering the cause of any reluctance to engage. Next, when employers are providing opportunities for the unemployed, it is necessary to discover both the rationale for such schemes and how they support job transitions and job progression. Studying this second set of questions enables us to engage with Peck and Theodore's (2000) desire to explore how employers link and reconcile the demand and supply sides of labour market policies, which has been seen as problematic and underdeveloped within the literature. This includes examining whether the Skills Escalator prompted managers to develop intermediate labour markets (Marshall and Macfarlane 2000); develop internal labour markets (Etherington and Jones 2004) and use labour market intermediaries to recruit workers (Benner 2003). Lastly, where HCD approaches are discerned, it enables us to explore further how policymakers can encourage the development of such a model (Lindsay et al 2007) and start outlining elements of a more progressive approach to welfare to work (Newman 2011).

A commission by the Department of Health enabled the authors to address these questions when they studied the implementation of the Skills Escalator and associated activities in NHS (England) over a 28 month period ending in June 2006. Two national telephone interview surveys were conducted. The first consisted of telephone interviews with learning and development personnel in 22 Strategic Health Authorities (SHAs) across England (the SHA Survey). At the time 28 SHAs were responsible for implementing policies of the Department of Health at a regional level. The second national survey (the Employer Survey) consisted of telephone interviews with training managers in 24 healthcare organisations across England (see McBride et al., 2006). This latter survey led to the selection of seven case study sites (three Acute (hospital) Trusts; two Primary Care Trusts (PCTs); one Mental Health Trust and one Ambulance Trust). ${ }^{1}$ 175 interviews were conducted across the case study sites, along with training observations and document review, to identify the roles and behaviours of employees, management, trade unions and partner organisations in the implementation of the Skills Escalator and associated activities. Several national policymakers were also interviewed. This article focuses on employer activities related to the recruitment of the unemployed.

\section{The HCD potential of the Skills Escalator}

Introduced in 2001 (Department of Health 2001), the Skills Escalator model divides NHS staff into seven categories with the purpose of making explicit the means of career

\footnotetext{
${ }^{1}$ Ethics approval for the project was granted in February and September 2004, with research clearance obtained at each site.
} 
progression from each level: (1) socially excluded; (2) unemployed; (3) roles requiring fewer skills and less experience; (4) skilled roles; (5) qualified professional roles; (6) more advanced skills and roles; and (7) more senior roles at the level of 'consultant' (p. 18). The application below of Lindsay et al's (2007, p. 542) criteria to distinguish employability approaches enables us to see both the HCD characteristics of the Skills Escalator and the potential for gaps to open up between policy and implementation (UKCES 2010).

Firstly, with regards to rationale, the following quote from a policymaker resonates with the aims of HCD approaches which seek to improve long-term employability through improved education, skills, health and personal development:

... a fantastic opportunity to use the economic spending power of the public sector, to deal with the problems of ill health, unemployment ... the Skills Escalator is the chance to break out of that vicious circle and get people into the world of work, out of unemployment, out of poverty, out of drug taking, out of crime.

Beyond this policymaker's desire to target the excluded, however, there was little indication in official documentation as to which groups should be prioritised for such activity. This is in contrast to schemes that usually prioritise groups for attention, such as those on long term incapacity benefits or those in disadvantaged urban areas (see Lindsay et al 2007, South et al 2011) and for whom progression might be seen as risky (Ray et al 2010).

Second, reference to 6 month programmes for the socially excluded and unemployed in the Skills Escalator provides an initial indication that the programme target is sustainable transitions to work, rather than a focus on getting people into work quickly. No central resources were available, however, for implementing the Skills Escalator for the socially excluded (Level 1) and unemployed (Level 2) and no mention is made of whether or how jobs could be released to provide an intermediate labour market for the unemployed or socially excluded, or how employers might resource this. In the context of the labour market shortages (Wanless 2002), such omissions might mean that in practice NHS employers are more focused on getting people recruited as quickly as possible to alleviate their immediate problems of insufficient capacity and unfilled vacancies. Added to the silence over which groups of unemployed to target, employers might be tempted to focus on filling immediate vacancies with those closest to returning to the labour market, such as women returners (Fletcher 2004). Third, there is no mention of the third characteristic of the HCD approach, that of an intervention model, which provides long-term training integrated with social care, education and health and high quality personalised support (Lindsay et al 2007), and which is a critical element of successful interventions (Hasluck and Green 2007).

Fourth, the policy documentation provides evidence of an HCD approach when analysed against the criteria - relationship to labour market. That this initiative requires NHS employers to take an HCD approach is illustrated by the Skills Escalator itself which indicates how employees can move up through all seven levels of the escalator - 
some of which are underpinned by central funding ${ }^{2}$. This contrasts with Pathways to Work and Working Neighbourhoods, where progression was less of a priority (Lindsay et al 2007, p. 548, 553) and evidence more broadly that few employers view low skilled work as a step towards progression (Devins et al 2011). A Department of Health policymaker informed us that the Skills Escalator was inspired by the Danish job rotation scheme. In their words, a unique feature of the NHS was that it provided the potential to incorporate not just entry level jobs [as in the Danish example] but a complete ladder 'from unemployment up to consultants', such that 'although you don't expect many people to run the whole route of the Skills Escalator, nonetheless it is possible to make every consecutive step'. As indicated earlier, however, such a dynamic process would require an active internal labour market but policy documents were silent on this issue and offered no guidance as to how organisations might generate jobs and support the aims of the Skills Escalator.

Fifth, as regards the criteria, relationship with individuals, no explicit explanation is given as to what the Department of Health thought would encourage the unemployed to participate in such schemes - other than an implicit assumption that they needed to be offered some appropriate opportunities, such as orientation programmes or placements in starter jobs. The documentation was completely silent as to whether the participants might be compelled to attend in order to continue receiving their Job Seekers Allowance, which no doubt reflects the heritage of the initiative as essentially an HR policy from the Department of Health rather than a collaborative concern with the Department of Work and Pensions.

Notwithstanding these potential limitations of the Skills Escalator, its inclusion of some key HCD characteristics and its application in a (then) expanding public sector provides a useful context to study. The next section presents four key findings of this research - limited employer engagement; motivations for employer engagement; structures for sustainable job transitions; and potential for job progression.

\section{'More important things to do'}

The predominant finding from the SHA Survey, Employer Survey and follow up case studies was that the NHS was not engaging widely with recruiting the unemployed. Only $36 \%$ of respondents to the SHA Survey identified the unemployed and socially excluded as part of their understanding of the Skills Escalator. This was matched by one third of respondents to the Employers Survey referring to the socially-excluded or unemployed. Only seven of the 24 employers had schemes for the unemployed, three of which were investigated further in case studies. Survey and case study material indicated two main reasons for this reluctance - existing staff were seen as the training priority, and there were 'more important things to do'.

SHA personnel indicated was training existing staff was the priority. Although they often had responsibility for facilitating the widening of access to education and training, this was understood as relating to NHS staff rather than the larger community. This was indicated by the majority of the SHA Survey respondents commenting that the

\footnotetext{
${ }^{2}$ Funds were available for discrete parts, e.g $£ 150$ Learning Accounts for those without NVQs 2, 3 (Skills Escalator Level 3); and nurse training secondments (Skills Escalator Level 4).
} 
Skills Escalator was about 'getting NHS staff into or back into education' and 'tapping into a huge chunk of the workforce who had more or less been ignored'. Surveyed employers indicated that the Skills Escalator was predominantly about facilitating the development of existing staff - particularly support staff. Where respondents talked of the Skills Escalator applying to those outside the organization, it was usually in relation to opening up new access points to school leavers. To some extent these responses are an indication that activity follows the money. As indicated, no central funds were available for pre-employment schemes. In contrast, monies were available to fund the NHS promise to provide National Vocational Qualifications (NVQs) and NHS Learning Accounts to existing staff without a Level 2 qualification. Thus, allocating this funding was the main concern of personnel within the SHAs and finding staff on whom this money could be spent was a dominant concern for employers more locally.

Many of the interviews emphasised that there were 'more important things to do'. SHA Survey respondents provide valuable insights into the competing priorities of employers. One observed that,

[the] service [is] being completely obsessed by short term targets when what we are talking about is long term needs so we are working in a very short term environment and trying to do things - [we are] saying to people we need this [in five years time] and they cross their eyes and say 'well I won't be a Chief Executive in 12 months if I haven't got this now.

The perception that central policy was limiting the ability to take longer term action was reiterated by another respondent,

the demand for work placements compared to the capacity of your service to support them is wild. There is no money to provide people to support something for no particular purpose, from the service point of view... PCTs are under such financial pressure that if they are given the choice between a long term issue and recruitment and retention ... why are they going to spend the money on something long term when they need to get through their short term targets?

Three employer organisations admitted that they were not 'actively' implementing the Skills Escalator at all with one citing 'quite a lot of other projects to do' and another that '[the organisation] is still relatively new and I'm not quite sure the structures and processes are in place to actually promote the escalator in any meaningful sense.'

Only two employer organisations (one Employer Survey respondent, one case study) appeared to have given serious consideration to pre-employment schemes before rejecting the idea. The Employer Survey respondent indicated the Learning and Skills Council was targeting 'people who are not employed or finding it difficult to be employed' but that they were unable to access this funding because 'that's not a target audience that I can attract', and they were not able to provide the salary for such posts. This reluctance was also underpinned by a belief that the funding would never cover all the training or the supervisory time required to protect both the learner on the ward and the 'vulnerable patients'. Pre-employment schemes had been mooted in the mental healthcare case study organisation but this had not been progressed because they were looking to relocate a number of their own staff due to organisational restructuring. Of all 
the employers interviewed in the national surveys and case studies, only one organisation, the ambulance employer, indicated that they did not need a pre-employment scheme because the supply of labour far outstripped demand and they had no problems recruiting.

In summary, these responses indicate that the majority of employers were pursuing some form of Skills Escalator activity but appeared to be engaging mainly with those aspects which were centrally-funded. The vast majority of employers had taken the decision not to implement levels 1 and 2 of the Skills Escalator for the socially excluded or unemployed. As indicated earlier, the study took place in a time of growth, tight labour markets and high turnover when we might expect more employer activity (Fletcher 2004; Devins and Hogarth 2005). Whilst some organizations indicated that they had no problems recruiting, labour shortages were an issue for some of the employers, as was turnover in many cases, especially in lower paid jobs. Yet this aspect of the Skills Escalator was insufficiently inspiring or these issues not sufficient motivation for these employers to develop active recruitment policies for the unemployed. This resonates with Devins and Hogarth's (2005, p.254) argument that employers are prepared to 'muddle through' with repeated short-term vacancies. However, it also provides a contrasting picture as employers (using central monies) were providing some learning opportunities to staff without a level 2 qualification, with case study sites providing evidence of expansive learning environments (Cox 2007) and progression routes for women (McBride 2011). This article now turns to those employers who, in the same context, went further and extended their Skills Escalator actively to include the unemployed and socially excluded.

\section{Employer motivations to engage}

Table 1 contains details of the three case study organisations discussed below. As indicated, there are some marked differences and commonalities between the three case study organisations and the activities they pursue. The approaches of City-wide PCT and Inner-City Acute portray a number of the characteristics of the HCD approach whilst Outer City Acute was closer to the WF approach (Lindsay et al 2007). A key distinction lay in the rationales for the different interventions. Interviews and document review indicated that City-wide PCT and Inner-City Acute were committed to attracting the unemployed into the organisation and had a high stated level of commitment to their respective communities. City-wide PCT had a particular desire to recruit more employees from within local Black and Minority Ethnic (BME) communities. An explicit objective of Inner-City Acute was to provide a 'Health Village' and help to support health gains through increasing economic activity amongst local people. 
Table 1: Organisational contexts and activities in case study sites at time of study ${ }^{3}$

\begin{tabular}{|c|c|c|c|c|}
\hline & City-wide PCT $^{4}$ & Inner City Acute & Outer City Acute & $\begin{array}{l}\text { National } \\
\text { Average }\end{array}$ \\
\hline No. of Staff & 3800 & 2000 & 4800 & \\
\hline Financial Status & $\begin{array}{l}\text { Small deficit } \\
0.5 \% \text { of turnover }\end{array}$ & In balance & $\begin{array}{l}\text { Large deficit } \\
8.8 \% \text { of turnover }\end{array}$ & \\
\hline $\begin{array}{l}\text { Labour stability index } \\
\text { non-medical staff }^{6}\end{array}$ & $89 \%$ & $85 \%$ & $89 \%$ & $85 \%$ \\
\hline $\begin{array}{l}\text { Ranking indices of } \\
\text { deprivation }\end{array}$ & $10^{8}$ & 6 & 53 & \\
\hline $\begin{array}{l}\text { Population of } \\
\text { working age in wards } \\
\text { served by } \\
\text { organisation }\end{array}$ & 608,000 & 162,700 & 180,000 & \\
\hline Economically active $^{9}$ & $74 \%$ & $52 \%$ & $70 \%$ & $75 \%$ \\
\hline $\begin{array}{l}\text { Econ. inactive and } \\
\text { wanting job }\end{array}$ & $5.2 \%(31,616)$ & $7.5 \%(12,203)$ & $6.5 \%(11,700)$ & $5 \%$ \\
\hline $\begin{array}{l}\text { Demographics }{ }^{10} \text { (incl. } \\
\text { largest ethnic group) }\end{array}$ & $\begin{array}{l}70 \% \text { white; (Asian or } \\
\text { British Asian })^{11}\end{array}$ & $\begin{array}{l}40 \% \text { white; (Black } \\
\text { African and Indian) }\end{array}$ & $\begin{array}{l}50 \% \text { white; (Asian/Asian British } \\
\text { and Black/Black British) }\end{array}$ & \\
\hline Work placements & $\begin{array}{l}\text { New roles } \\
\text { Replacing secondees }\end{array}$ & Voluntary placements & Parallel to current vacancies & \\
\hline $\begin{array}{l}\text { Internal Labour } \\
\text { Market }\end{array}$ & Within Directorates & Organisation wide & Within occupations & \\
\hline
\end{tabular}

These motivations contrast with those of Outer-City Acute which relate far more to the needs of the employer rather than the needs of the unemployed. When questioned, it appeared that the initial motivation of their activities for the unemployed was the existence of 80 unfilled Health Care Assistants (HCA) vacancies. There had been problems with HCAs recruited from outside the local area leaving once they had gained experience. As one manager commented, 'we didn't seem to be attracting any of the local people'. This limited organisational commitment was apparently matched by resistance from managers to engaging the unemployed. Although the scheme had senior backing, interviewees reported 'some degree of prejudice, or misunderstanding' with one indicating that there had been 'a real backlash'.

As illustrated further below, geographical location and financial stability are key elements in explaining the different approaches. First, Inner-City Acute and parts of Citywide PCT were located in deprived inner-city areas with high levels of unemployment (see Table 1) which enabled them to work with other agencies and access additional

\footnotetext{
${ }^{3}$ Figures from case study documentation, unless otherwise indicated

${ }^{4}$ The population covered by this organisation live in a range of wards, some of which have high levels of deprivation, others are considerably more affluent

${ }^{5}$ NHS Deficits First Report of Session 2006-7, vol. 1, Report for Parliamentary Health Select Committee, House of Commons Stationery Office, London

${ }^{6}$ Figures from www.ic.nhs.uk

${ }^{7}$ English indices of deprivation 2007: local authority summaries, Department of Communities and Local Government

${ }^{8}$ Example of deprivation within one of inner city wards covered by the organization

${ }^{9}$ ONS labour market reviews

${ }^{10}$ ONS

${ }^{11}$ City-wide demographics but includes more diverse wards, e.g. demographics of $44 \%$ white, Asian largest ethnic group.
} 
funding. Second, at the time of the study, both employers were financially stable which arguably gave them some confidence about their longer-term planning. This contrasts with Outer-City Acute. During the study the organisation was operating a large budget deficit, had missed its financial target for the previous year and was subject to a Strategic Review imposed by central government. Interviews revealed that financial constraints had led to a recruitment freeze, despite staff shortages across the organisation, a cut in the training budget and an urgent need to curtail a staff agency over-spend. They also led to a $50 \%$ reduction in clinical educators and difficulties in releasing staff for training. The following sections indicate how these constraints fed into the short-term activities of Outer-City Acute, together with an indication of how funding and financial stability fed into the HCD approaches of City-wide PCT and Inner-City Acute.

\section{Job transition: recruitment to jobs or to the organisation?}

The short-term nature of the activities of Outer City Acute is underlined by the duration of their scheme for the long-term unemployed. This Trust provided an intermediate labour market for those who had been unemployed for more than a year using monies from the European Social Fund. This programme had ceased at the time of the fieldwork. The demand-responsive nature of the scheme was indicated by the recruitment of the long-term unemployed to 42 week work placements where there were current vacancies. This resulted in 28 people being recruited into full-time employment in a range of roles, including secretarial posts, receptionists, porters, HCAs and radiography assistants. Whilst this ensured that work placements were integral to the organisation, because this was not the only recruitment pathway to these jobs it resulted in some anomalies. For example, one participant commented that his inability to earn overtime during his placement (to fit in with benefit arrangements) meant he was treated less favourably than people who had 'just come in off the streets' and were doing the same job.

That this programme existed at all was due to the enthusiasm of two people from within the Education and Training department but this provided its own constraints. This isolation meant these enthusiasts were less able to address managerial resistance to the scheme. Indeed, the ability to dismiss participants with a month's notice if they did not achieve their competencies had been 'something to dangle to the managers', because 'some staff were saying, 'oh, you're taking people in that nobody else would employ, you're taking misfits'. These staff also had less capacity to develop relations within their local economies, leading to fewer and shallower relationships. For example, Outer-City Acute reported a distant relationship with employment agencies which reportedly sent inappropriate individuals for interview. The scheme's co-ordinators indicated that this was a case of the employment agencies working to targets of their own and failing to adequately consider the support needed for both individuals and the organisation. On the other hand, it could be taken as another indication that Outer-City Acute were only interested in filling immediate job vacancies and were taking those 'closest to market' to appease managers who were already assuming that participants would be 'misfits' underlying Fletcher's (2004) concern as to who determines 'appropriateness' in demandled schemes. This provides a contrast to the manner in which City-wide PCT and InnerCity Acute were taking more of an HCD approach and were attracting the unemployed to 
the organisation rather than to specific jobs. This is best illustrated through two schemes developed by City-wide PCT.

The first scheme involved the setting up of an intermediate labour market in which trainees could take on the role of a Community Family Worker whilst studying for an NVQ2 level qualification. Its embedded nature within the community is illustrated by this new role being developed in conjunction with Barnados, Sure Start and a local Further Education college with the aim of it suiting a variety of settings such as health centres, health visitor teams, schools and community organisations. There were a number of transition routes from this scheme. Of the 70 participants completing the programme in its first year, 28 were employed by the Trust, 24 were employed in other public health/ community roles and 5 went into further education.

The second scheme was similar to a job rotation scheme whereby placement jobs were created through the training of existing staff. Approximately thirty social care workers per year were seconded to nurse training. This released jobs for trainees in an intermediate labour market environment which was supported by the Learning and Skills Council and New Deal funding. The depth of its relationships within the community is illustrated by its use of a labour market intermediary which brokered the relationship between the participant and employer and placed applicants in work placements in Trust care homes. This relationship appeared to meet conditions for effective labour market intermediaries whereby both parties need a good understanding of the project and how it links to wider employment strategies for improving equality of opportunity (Benner 2003; Fletcher 2004). This labour market intermediary was closely linked to the local African-Caribbean community, where it had been established since 1996 as a registered charity to provide support for vulnerable people in housing association properties. Citywide PCT had been working with it for six years at the time of fieldwork. This relationship played a part in enabling the organisation to meet its objective of increasing the number of BME applicants and employees. For example, $70 \%$ of participants on this programme were from BME groups. Again, this was a large scheme involving 156 people over a 3 year period to June 2005. Of these, 53 gained Trust employment, eight of whom were beginning nurse training. A further 96 moved into health and social work for other employers in the city.

The above schemes illustrate how City-wide PCT created jobs or training schemes which would provide valuable experience that was integral to the organisation or similar organisations in the city. In doing so, it can be contrasted with Outer-City Acute which was not linking its employment scheme to an internal labour market and could be characterised as using the scheme to exploit existing vacancies (Peck and Theodore 2000). In addition, the development of the new role of Community Family Worker appears to meet Peck and Theodore's desire for a social-economy and public sector initiative which enables job creation to be addressed alongside service delivery. As indicated, these schemes required managers to think differently about how to fill vacancies. They also needed large-scale external funding and the capacity to work with and draw on the expertise of others in the community. Whilst these aspects were fragmented across different Directorates within City-wide PCT they were concentrated in one place within Inner-City Acute. This enabled them to better execute an organisationalwide workforce development plan which matched the progression aspirations of the Skills Escalator. 


\section{Job progression: from unemployment to consultant level?}

Inner-City Acute articulated their desire to employ members of the local community and facilitate the mobility of their staff up hierarchies, through occupational boundaries and between organisations. Their internal labour market was underpinned by a workforce development plan developed with a local University 'to give all staff in the Trust access to academic and skills based training' (website citation). It was operationalised by a dedicated team of 10 staff working with managers and clinicians across the organisation. In common with City-wide PCT, attracting members of the community into the organisation's labour market did require external funding and local collaboration. For example, the on-site job brokerage service with the specific objective of attracting the socially excluded and unemployed to new vacancies was a partnership with the local authority and Jobcentre Plus funded by $£ 245,000$ from the Neighbourhood Renewal Fund. Likewise, the six-week orientation programme (accredited by the Open College Network) was funded by Single Regeneration Budget 6 monies.

In return for this investment of staff and resources, Inner-City Acute believed they were now seen as 'the place to be' (HR manager). Turnover had fallen by two percentage points in the previous year and its vacancy rate had fallen from 16 to 10 per cent. This had enabled the organisation to reduce significantly its spending on agency staff. Notwithstanding some challenges which will be discussed later, the following sections outline how this organisation was operationalising a key characteristic of the HCD approach that 'up-skills the job seeker to expand [their] range of opportunities; encourages and supports progression in [the] workplace' (Lindsay et al 2007:542). Using interview transcripts and documentary evidence, possible pathways can be traced through the organisation from unemployment to consultant level roles:

If a woman had never worked or was a newly arrived immigrant, they might be attracted to the Community Enhancement Programme which promotes awareness of local health services, family health, and the identification of employment prospects in health and social care. Leaving with a Level 1 certificate, participants would be introduced to the organisation's scheme for voluntary work. Interviewees who had been through the scheme spoke favourably of the opportunities this had offered them, including gaining employment after periods of volunteering, accessing courses delivered by community organisations and taking placements in the trust.

Alternatively, someone might work for a private contractor at Inner-City Acute and be amongst the thirty staff who joined the scheme which gave them 56 hours of Level 1 accredited training and the opportunity to gain direct employment in the NHS as an HCA or ward housekeeper. A supervisor from the external contractor indicated that they encouraged their staff to take part in the training as although 'it's a hard thing for us, I look at the positive side of it, that I'm helping the community ... I'm helping the NHS'. Participants who had moved between the organisations indicated their satisfaction with the improved terms and conditions of the NHS.

From here, an HCA might apply to train for the newly developed role of the Clinical Assistant Practitioner and end up with a Foundation degree, or a more experienced HCA might apply for secondment to nurse training. Once in possession of a 
professional registration, staff might apply for specialised clinical training or take a management course to gain more advanced, consultant level roles. Thus, it is technically possible to go from unemployment to consultant level. In practice, it is reliant on three essential elements. First, sufficient funding needs to be available for each aspect whether for the training or monies to replace the staff trainee. Secondly, it requires line managers to regularly review the development needs of their staff and release them for training - both of which were indicated as issues in some areas of the organisation. Thirdly, there need to be jobs for people to progress into. This aspect is of particular importance in the current climate of high unemployment.

The contentious aspect of this workforce development plan relates to the progression opportunities provided by unpaid work experience. By providing such opportunities the organisation arguably established a quasi-intermediate labour market. However, the possibility of volunteering for extended periods raised concerns among trade union interviewees that it was insufficiently regulated and exploitative. This potential for both progression and exploitation is illustrated by the South Asian woman who had attended the Community Enhancement Programme and was now working in her first paid job (as an HCA) having volunteered for 16 hours per week over a six month period in order to learn about the job and gain confidence in the workplace. At the time of the study, such participation was voluntary. Higher unemployment rates, a changing discourse, and subsequent benefit changes could see such opportunities become mandatory, despite studies indicating the counterproductive nature of such work experience being compulsory (Newman 2011).

\section{Discussion and Conclusions}

Four contributions arise from this study of NHS employers and their responses to a framework which encouraged them to think about the inclusion of the socially excluded and unemployed in their workforce development plans. First, whilst there is a growing acceptance that sustainable employment presents a more viable option to support routes out of escaping unemployment and poverty, this article indicates very clearly that it requires governments to do more than merely encourage employers to engage with specific schemes for the unemployed or invest in HR practices which facilitate job transitions and job progression (DBIS 2010; UKCES 2011a). At the time of this study, the UK had a buoyant economy, the NHS was expanding and NHS managers were facing labour shortages - and yet NHS managers were still reluctant to adopt a framework which had the potential to bring new people into their organisations, develop them and retain them. This has important implications for policy in the anticipated growth years of the future. It underlines the enormity of the 'pretty big gamble' (Payne and Keep 2011, p. 15) that employers will boost their investment in training in a voluntarist environment. To be blunt - why should they? If NHS employers - in an expanding sector - had 'more important things to do', then why would employers struggling to survive and grow in the future react any differently? Whilst it may appear eminently sensible to invest in order to grow, as indicated in the SHA Survey if organisations are working in the 'very short term environment' they become 'completely obsessed with short term targets' regardless of 
long term needs. Time again, surely, to re-think the incentive structures in which firms operate and which shape their behaviour (Payne and Keep 2011, p. 17).

This leads us to the second contribution - what lessons can be learned from the motivations of the three case study organisations which did attract, train and recruit the unemployed? In the first place, they were all motivated by the need to fill vacancies but the motivation for City-wide PCT and Inner-City Acute to develop their longer-term HCD approaches derived from the organisations' aims of having workforces that were more representative of their local community and to use employment to tackle deprivation and health inequalities. It is difficult to see how the relentless drive to maximise short term shareholder returns in the UK context could do anything but quash such aspirations in the private sector. In the absence of moves to change such incentive structures at a national level, local authorities have the most potential to develop incentive structures at a local level (Houghton 2008, Jones 2010, Fuller et al 2010). More generally, as significant local employers, public sector organisations are in a strong position to provide longer-term commitments to their communities. Indeed, whilst NHS employers were not taking on the unemployed, they were busy training their own staff many of whom were doing lower-skilled jobs. Whilst developing local solutions might fit with the 'localism' agenda, however, it does not fit with the expressed desire of the CLC to reduce the public sector - both in numbers and in financial support. Thus a failure to reflect on private sector (dis)incentive structures and the continued intention to squeeze the public sector will undermine efforts to promote sustainable employment in the immediate future.

The third contribution comes from practical illustrations of internal labour markets and their necessity for sustainable transitions and progression. This is most vividly captured in Inner-City Acute which provides a working example of using the Skills Escalator as an organisation-wide workforce development plan. This is not to say that it was working perfectly or that it could not be improved, but it demonstrates the need for, and potential of, organisational-wide thinking. The relationship between the intermediate labour market and internal labour market is most important to note. Employers are being encouraged to take on apprenticeships (DBIS 2010) but unless the organisation integrates such positions within an overall workforce development plan, skills will remain under-utilised and, at worst, apprentices will receive college rather than workplace training. Internal labour markets have tended to take a backseat in recent years. At times this has been the result of the drive to outsource a number of services - an enthusiasm which is being encouraged within the public sector. However, there is a need to think through the implications of such policy more carefully - particularly in large organisations. Labour turnover and retirements within organisations like NHS employers will release a relatively consistent level of vacancies which, with an organisation-wide perspective, could enable more sustainable employment prospects for those both outside and within the organisation. This leads us to the fourth contribution of this work.

These case studies have shown the full range of activities and resources which employers need to engage in if they are to provide sustainable employment for their communities. Extant literature indicates the mechanisms that are required but these case studies provide evidence of 'the work' of such activities. In the context of shorter-term requirements, perhaps it is no wonder that managers indicated that they had more important things to do than occupy themselves with this resource-hungry work. It is no 
coincidence either that the organisation which developed the organisation-wide workforce development plan did so with the aid of a dedicated team of ten. Their task was not aided by the limited information they were given by policymakers - which perhaps gives us some insights too into the policy-implementation gap around high performance workplaces (UKCES 2010). Although materials and good practice examples were provided (Department of Health 2004), these were silent on essential issues such as how orientation programmes and pre-employment training might be financed, how an internal labour market would facilitate the development of an intermediate labour market and the benefits of selecting a labour market intermediary which was closely connected to the local community. In addition, the need for better integration of internal and intermediate labour markets and closer collaboration with intermediaries is likely to be challenged by the breaking up of employment services in the UK, where successive governments have encouraged an increasingly fragmented system with greater use of private sector providers.

To conclude, Newman (2011) calls for a more progressive approach to welfare to work but warns that it is difficult to develop such a progressive agenda within the current discourse. This study indicates that a progressive agenda would move resources from supply-side to demand-side solutions. It would invest in local authorities who took a longer-term perspective on sustainable employment. Investment in employers would be made conditional on the organisational integration of placements and apprenticeships within internal labour markets. Finally, managers would be provided with more practical support to pull all the pieces together.

\section{Acknowledgements}

This article is based on research gathered during the study of skills development activities commissioned by the Department of Health, Policy Research Programme. The full research team comprises Anne McBride, Annette Cox, Stephen Mustchin, Marilyn Carroll, Paula Hyde, Elena Antonacopoulou, Kieran Walshe and Helen Woolnough. The article represents the views of the authors and not necessarily those of the Department of Health. The authors would like to thank Caroline Lloyd, Ian Greener, Miguel Martinez-Lucio and Paula Hyde for their comments on earlier drafts.

\section{References}

Bach, S., 2004. Employment Relations and the Health Service: The Management of Reforms. London: Routledge.

Benner, C., 2003. Labour flexibility and regional development: the role of labour market intermediaries. Regional Studies, 37 (6-7), 621-633.

Clayton N., and Brinkley, I., 2011. Welfare to What? Prospects and challenges for employment recovery. Lancaster: The Work Foundation.

Convery, P. 2009. Welfare to Work - From Special Measures to 80 Per Cent Employment. Local Economy, 24 (1), 1-27.

Cox, A. 2007. Re-visiting the NVQ Debate: 'Bad' Qualifications, Expansive Learning Environments and Prospects for Upskilling workers. SKOPE Research Paper 71. 
ESRC funded Centre on Skills, Knowledge and Organisational Performance, Oxford.

Daguerre, A. with Etherington, D., 2009. Active labour market policies in international context: what works best? Lessons for the UK. Department for Work and Pensions, Working Paper No. 59. Norwich: Her Majesty's Stationery Office.

Department of Business, Industry and Skills (DBIS), 2010. Investing in Skills for Sustainable Growth. London: DBIS.

Department of Health, 2000. The NHS Plan. London: Department of Health.

Department of Health, 2001. Working Together, Learning Together: A Framework for Lifelong Learning for the NHS. London: Department of Health.

Department of Health, 2002. HR in the NHS Plan. London: Department of Health.

Department of Health, 2004. Skills Escalator Resource Pack: Achieving your Potential. London: Department of Health.

Devins, D. and Hogarth, T., 2005. Employing the Unemployed: Some Case Study Evidence on the Role and Practice of Employers. Urban Studies, 42 (2), 245-256.

Devins, D., Bickerstaff, T., Nunn, A., Mitchell with McQuaid, R., Egdell, V., Lindsay, C., 2011. The Role of Skills from Worklessness to Sustainable Employment with Progression. UKCES Evidence Report 38, Wath-upon-Dearne: UKCES.

Etherington, D., Jones, M., 2004. Beyond contradictions of the workfare state? Denmark, welfare-through-work, and the promise of job rotation. Environment and Planning C: Government and Policy. 22, 129-148.

Fletcher, D., 2004. Demand-led programmes: challenging labour market inequalities or reinforcing them? Environment and Planning C: Government and Policy. 22 (1), 115-128.

Fuller, A., Unwin, L., Guile, D., and Rizvi, S., 2010. Economic Regeneration, Social Cohesion, and the Welfare-to-Work Industry: Innovation, Opportunity and Compliance in the City-Region, Centre for Learning and Life Chances in Knowledge Economies and Societies at: http://www.llakes.org.uk.

Gore, T., 2005. Extending Employability or Solving Employers' Recruitment Problems? Demand-led Approaches as an Instrument of Labour Market Policy. Urban Studies, 42 (2), 341-353.

Hasluck, C. and Green A.E., 2007. What works for whom? A review of evidence and meta-analysis for the Department of Work and Pensions. Department for Work and Pensions Research Report 407. Leeds: Her Majesty's Stationery Office.

Houghton, S., Dove, C., Wahhab, I., 2008. Tackling Worklessness: A Review of the contribution and role of English local authorities and partnerships. London: Department for Communities and Local Government.

Jones, A., 2010. Local Work: Empowering Local Government to tackle worklessness, London: Local Government Information Unit.

Keep, E., Lloyd, C. and Payne, J., 2010. Skills policy and the displacement of industrial relations. In T. Colling and M. Terry, eds. Industrial Relations: Theory and Practice. Chichester: Wiley.

Lindsay, C., McQuaid, R., Dutton, M., 2007. New Approaches to Employability in the UK: Combining 'Human Capital Development' and 'Work First' strategies? Journal of Social Policy. 36 (4), 539-560. 
Marshall, B. and MacFarlane, R., 2000. The Intermediate Labour Market: A Tool for Tackling Long-term Unemployment, York: Joseph Rowntree Foundation.

McBride, A., Cox, A., Mustchin, S., Carroll, M., Hyde, P., Antonacopoulou, E., Walshe, K. and Woolnough, H. (2006) Developing Skills in the NHS. Manchester: University of Manchester.

McBride, A. (2011) Lifting the Barriers? Workplace Education and Training, Women and Job Progression. Gender Work and Organization, 18 (5), 528-547.

McQuaid, R. and Lindsay, C., 2005. The concept of employability. Urban Studies 42 (2), 197-219.

McQuaid, R., Fuertes, V., Egdell, V., Bergmann, A. with Green, A.E., 2011. Promoting investment and increasing employment among the economically inactive - a review of best practice, Final Report to the Department of Enterprise, Trade and Investment, Northern Ireland, Employment Research Institute, Edinburgh Napier University, www.napier.ac.uk/eri.

National Audit Office, 2007. Sustainable employment: supporting people to stay in work and advance. London: The Stationery Office.

Newman, I., 2011. Work as a route out of poverty: a critical evaluation of the UK welfare to work policy. Policy Studies, 32 (2), 91-108.

Parker, E., 2001. The Development of Job Rotation in the UK: Implications for London.

London: Department of Geography, Queen Mary University of London.

Payne, J. and Keep, E., 2011. One Step Forward, Two Steps Back? Skills Policy in England under the Coalition Government, SKOPE Research Paper No. 102, July 2010. Cardiff University, SKOPE.

Peck, J. and Theodore, N., 2000. Beyond 'employability'. Cambridge Journal of Economics, 24 (6), 729-749.

Ray, K., Hoggart, L., Vegeris, S., Taylor, R., 2010. Better off working? Work, poverty and benefit cycling. York: Joseph Rowntree Foundation.

South, J., Jackson, K.L., Warwick-Booth, L., 2011. The community health apprentices project - the outcomes of an intermediate labour market project in the community health sector. Community, Work \& Family, 14(1), 1-18.

Taylor-Gooby, P., 2008. The New Welfare State Settlement in Europe. European Societies, 10 (1), 3-24.

UKCES (UK Commission for Employment and Skills), 2009. Ambition 2020: World Class Skills and Jobs for the UK. Wath-upon-Dearne: UKCES.

UKCES, 2010. High Performance Working: A Policy Review. Evidence Report 18. Wathupon-Dearne: UKCES.

UKCES, 2011a. Review of Employment and Skills. Wath-upon-Dearne: UKCES.

UKCES, 2011b. Our Work, UKCES. Available from: http://www.ukces.org.uk/ourwork [Accessed 16 December 2011].

Wanless, D., 2002. Securing our Future Health - Taking a long term view. London: HM Treasury. 